\title{
Aestuariicola saemankumensis gen. nov., sp. nov., a member of the family Flavobacteriaceae, isolated from tidal flat sediment
}

Correspondence

Jung-Hoon Yoon

jhyoon@kribb.re.kr
Jung-Hoon Yoon, So-Jung Kang, Yong-Taek Jung and Tae-Kwang Oh

Korea Research Institute of Bioscience and Biotechnology (KRIBB), PO Box 115, Yusong, Taejon, Republic of Korea

\begin{abstract}
A Gram-negative, non-motile, pleomorphic bacterial strain, designated SMK-142 ${ }^{\top}$, was isolated from a tidal flat of the Yellow Sea, Korea, and was subjected to a polyphasic taxonomic study. Strain SMK-142 ${ }^{\top}$ grew optimally at $\mathrm{pH} 7.0-8.0,25^{\circ} \mathrm{C}$ and in the presence of $2 \%(\mathrm{w} / \mathrm{v}) \mathrm{NaCl}$. Phylogenetic analyses based on $16 \mathrm{~S}$ rRNA gene sequences showed that strain SMK-142 ${ }^{\top}$ clustered with Lutibacter litoralis with which it exhibited a 16S rRNA gene sequence similarity value of $91.2 \%$. This cluster joined the clade comprising the genera Tenacibaculum and Polaribacter at a high bootstrap resampling value. Strain SMK- $142^{\top}$ contained MK- 6 as the predominant menaquinone and iso- $\mathrm{C}_{15: 0}$, iso- $\mathrm{C}_{15: 1}$ and iso- $\mathrm{C}_{17: 0} 3-\mathrm{OH}$ as the major fatty acids. The DNA G +C content was 37.2 mol\%. Strain SMK $-142^{\top}$ was differentiated from three phylogenetically related genera, Lutibacter, Tenacibaculum and Polaribacter, on the basis of low 16S rRNA gene sequence similarity values and differences in fatty acid profiles and in some phenotypic properties. On the basis of phenotypic, chemotaxonomic and phylogenetic data, strain SMK-142 ${ }^{\top}$ represents a novel genus and species for which the name Aestuariicola saemankumensis gen. nov., sp. nov. is proposed (phylum Bacteroidetes, family Flavobacteriaceae). The type strain of the type species, Aestuariicola saemankumensis sp. nov., is $\mathrm{SMK}-142^{\top}\left(=\mathrm{KCTC} 22171^{\top}=\right.$ CCUG $\left.55329^{\top}\right)$.
\end{abstract}

A tidal flat is a part of a coast that is covered with seawater during a flood-tide and left covered with mud or slime at ebb-tide. Tidal flats are recognized as a good environment from which to screen novel and useful micro-organisms (Yoon et al., 2003, 2004; Kim et al., 2005; Lim et al., 2006; Nam et al., 2007). In recent years, bacterial taxa belonging to the phylum Bacteroidetes have been isolated from a variety of tidal flats on the west coast of the Korean peninsula (Yi \& Chun, 2004; Jung et al., 2005, 2006; Choi \& Cho, 2006; Choi et al., 2006; Yoon et al., 2006a). In this study, we describe a bacterial strain, designated SMK- $142^{\mathrm{T}}$, which was isolated from a tidal flat sediment at Saemankum on the west coast of Korea. Comparative 16S rRNA gene sequence analyses indicated that the strain was phylogenetically affiliated to the family Flavobacteriaceae (Bernardet \& Nakagawa, 2006; Bowman, 2006), phylum Bacteroidetes. The aim of the present work was to determine the exact taxonomic position of strain $\mathrm{SMK}-142^{\mathrm{T}}$ by using a polyphasic approach that included the determination of phenotypic properties and a detailed phylogenetic investigation based on $16 \mathrm{~S}$ rRNA gene sequences.

The GenBank/EMBL/DDBJ accession number for the 16S rRNA gene sequence of strain SMK-142 ${ }^{\top}$ is EU239499.
Strain SMK $-142^{\mathrm{T}}$ was isolated by using the dilution plating technique at $25{ }^{\circ} \mathrm{C}$ on marine agar 2216 (MA; Difco). The morphological, physiological and biochemical characteristics of strain SMK-142 ${ }^{\mathrm{T}}$ were investigated using routine cultivation on MA at $25{ }^{\circ} \mathrm{C}$. Cell morphology was examined using light microscopy (E600; Nikon) and transmission electron microscopy (CM-20; Philips). Flagellation was investigated by using transmission electron microscopy on cells from an exponentially growing culture that were negatively stained with $1 \%(\mathrm{w} / \mathrm{v})$ phosphotungstic acid. Grids were examined after being air-dried. Gliding motility was investigated as described by Bowman (2000). The Gram reaction was determined by using the bioMérieux Gram stain kit according to the manufacturer's instructions. Growth under anaerobic conditions was determined after incubation in a Forma anaerobic chamber on MA and on MA supplemented with $0.1 \%(\mathrm{w} / \mathrm{v})$ potassium nitrate, both of which had been prepared under a nitrogen atmosphere. Growth in the absence of $\mathrm{NaCl}$ was investigated using trypticase soy broth prepared according to the formula of the Difco medium except that $\mathrm{NaCl}$ was excluded. Growth with various $\mathrm{NaCl}$ concentrations $(0.5 \%, \mathrm{w} / \mathrm{v} ; 1.0-7.0 \%, \mathrm{w} / \mathrm{v}$, in increments of $1.0 \%)$ was investigated in marine broth 2216 (MB; Difco) and trypticase soy broth (Difco). Growth at various tempera- 
Table 1. Differential phenotypic characteristics of strain SMK-142 ${ }^{\top}$ and related genera of the family Flavobacteriaceae

Taxa: 1, strain SMK-142 ${ }^{\mathrm{T}}$; 2, Lutibacter (data from Choi \& Cho, 2006); 3, Tenacibaculum (Choi \& Cho, 2006; Jung et al., 2006; Sheu et al., 2007); 4, Polaribacter (Gosink et al., 1998; Nedashkovskaya et al., 2005; Choi \& Cho, 2006; Yoon et al., 2006b). +, Positive reaction; -, negative reaction; v, variable reaction; NA, data not available.

\begin{tabular}{|c|c|c|c|c|}
\hline Characteristic & 1 & 2 & 3 & 4 \\
\hline Cell morphology & Rods, ovals or cocci & Rods & Rods & Rods or filaments \\
\hline Gliding motility & - & - & $\mathrm{V}^{*}$ & - \\
\hline Colour & Yellow & Yellow & Yellow or pale yellow & Orange, salmon pink \\
\hline Shape & Entire & Entire & Uneven edge & Entire \\
\hline pH 6 & + & - & + & $\mathrm{NA}$ \\
\hline $25{ }^{\circ} \mathrm{C}$ & + & + & + & - \\
\hline $37^{\circ} \mathrm{C}$ & - & - & $\mathrm{V}$ & - \\
\hline Oxidase & + & - & + & $\mathrm{V}$ \\
\hline Nitrate reduction & - & - & $\mathrm{v}$ & $\mathrm{v} \dagger$ \\
\hline \multicolumn{5}{|l|}{ Utilization of: } \\
\hline Sucrose & - & - & $\mathrm{V} \neq$ & $\mathrm{v}$ \\
\hline L-Glutamate & - & - & $\mathrm{v}$ & $\mathrm{v}$ \\
\hline L-Leucine & - & + & $\mathrm{v} \S$ & -9 \\
\hline L-Proline & - & - & $\mathrm{v}$ & -9 \\
\hline Citrate & - & + & $\mathrm{V}$ & - \\
\hline Pyruvate & - & + & -11 & -9 \\
\hline Succinate & - & + & -11 & -9 \\
\hline Major fatty acids & $\begin{array}{l}\text { iso- } \mathrm{C}_{15: 0}, \text { iso- } \mathrm{C}_{15: 1} \\
\text { iso- } \mathrm{C}_{17: 0} 3-\mathrm{OH}\end{array}$ & $\begin{array}{c}\text { iso- } \mathrm{C}_{15: 0} 3-\mathrm{OH}, \\
\text { iso- } \mathrm{C}_{15: 0} \text {, anteiso- } \mathrm{C}_{15: 0}, \\
\text { iso- } \mathrm{C}_{16: 0} 3-\mathrm{OH}\end{array}$ & $\begin{array}{c}\mathrm{C}_{16: 1} \omega 7 c \text { and/or } \\
\text { iso- } \mathrm{C}_{15: 0} 2-\mathrm{OH}, \text { iso- } \mathrm{C}_{15: 0} \\
\text { iso- } \mathrm{C}_{17: 0} 3-\mathrm{OH}\end{array}$ & $\begin{array}{l}\text { iso- } \mathrm{C}_{15: 0} 3-\mathrm{OH}, \\
\text { iso- } \mathrm{C}_{15: 0} \text {, iso- } \mathrm{C}_{15: 1} \\
\quad \text { or iso- } \mathrm{C}_{13: 0}\end{array}$ \\
\hline
\end{tabular}

*All species except Tenacibaculum skagerrakense are positive for this characteristic.

$\dagger$ All species except Polaribacter glomeratus are negative for this characteristic.

‡Only T. skagerrakense is positive for sucrose.

§Only T. skagerrakense is weakly positive for L-leucine.

IIData not available for Tenacibaculum lutimaris and Tenacibaculum aestuarii.

SData not available for Polaribacter butkevichii.

tures $\left(4,10,15\right.$ and $20{ }^{\circ} \mathrm{C}$ and from 25 to $37{ }^{\circ} \mathrm{C}$ in $1{ }^{\circ} \mathrm{C}$ increments) was measured on MA. The $\mathrm{pH}$ range for growth was determined in $\mathrm{MB}$ adjusted to various $\mathrm{pH}$ values ( $\mathrm{pH} 4.5-9.5$, in increments of $0.5 \mathrm{pH}$ units) by the addition of $\mathrm{HCl}$ or $\mathrm{Na}_{2} \mathrm{CO}_{3}$. Catalase and oxidase activities were determined as described by Cowan \& Steel (1965). Hydrolysis of casein, starch, Tweens 20, 40, 60 and 80, hypoxanthine, tyrosine and xanthine was tested on MA, using the substrate concentrations described by Cowan \& Steel (1965). Hydrolysis of aesculin, gelatin and urea and reduction of nitrate were investigated as described previously (Lányí, 1987) with the modification that artificial seawater was used for the preparation of media. The artificial seawater contained the following $\left(1^{-1}\right.$ distilled water): $23.6 \mathrm{~g} \mathrm{NaCl}, 0.64 \mathrm{~g} \mathrm{KCl}, 4.53 \mathrm{~g} \mathrm{MgCl}_{2} \cdot 6 \mathrm{H}_{2} \mathrm{O}$, $5.94 \mathrm{~g} \mathrm{MgSO}_{4} \cdot 7 \mathrm{H}_{2} \mathrm{O}$ and $1.3 \mathrm{~g} \mathrm{CaCl}_{2} \cdot 2 \mathrm{H}_{2} \mathrm{O}$ (Bruns et al., 2001). $\mathrm{H}_{2} \mathrm{~S}$ production was tested as described previously (Bruns et al., 2001). The presence of flexirubin-type pigments was investigated as described by Reichenbach (1992). For analysis of the pigment-absorption spectrum, strain SMK-142 $2^{\mathrm{T}}$ was cultivated aerobically in the dark at $30{ }^{\circ} \mathrm{C}$ in $\mathrm{MB}$. The culture was centrifuged, washed twice using a MOPS buffer (MOPS/NaOH, $0.01 \mathrm{M}$; KCl, $0.1 \mathrm{M}$; $\mathrm{MgCl}_{2}, 0.001 \mathrm{M} ; \mathrm{pH} 7.5$ ) and disrupted by sonication with a Branson 450 sonifier. After removal of cell debris by centrifugation, the absorption spectrum of the supernatant was examined on a Beckman Coulter DU800 spectrophotometer. Pigments were also extracted using acetone/ 
methanol $(1: 1, \mathrm{v} / \mathrm{v})$. Susceptibility to antibiotics was investigated on MA plates by using antibiotic discs containing the following: $100 \mathrm{U}$ polymyxin $\mathrm{B}, 50 \mu \mathrm{g}$ streptomycin, $20 \mathrm{U}$ penicillin $\mathrm{G}, 100 \mu \mathrm{g}$ chloramphenicol, $10 \mu \mathrm{g}$ ampicillin, $30 \mu \mathrm{g}$ cephalothin, $30 \mu \mathrm{g}$ gentamicin, $5 \mu \mathrm{g}$ novobiocin, $30 \mu \mathrm{g}$ tetracycline, $30 \mu \mathrm{g}$ kanamycin, $15 \mu \mathrm{g}$ lincomycin, $15 \mu \mathrm{g}$ oleandomycin, $30 \mu \mathrm{g}$ neomycin and $100 \mu \mathrm{g}$ carbenicillin. Growth on various substrates was tested in a basal medium containing $0.2 \mathrm{~g} \mathrm{NaNO}_{3}, 0.2 \mathrm{~g}$ $\mathrm{NH}_{4} \mathrm{Cl}$ and $0.05 \mathrm{~g}$ yeast extract in $1 \mathrm{l}$ artificial seawater (Bruns et al., 2001) as described by Suzuki et al. (2001). Enzyme activities were determined, after incubation for $8 \mathrm{~h}$ at $25{ }^{\circ} \mathrm{C}$, by using the API ZYM system (bioMérieux).

Cell biomass for DNA extraction and for isoprenoid quinone analysis was obtained from a culture grown for 3 days in $\mathrm{MB}$ at $25^{\circ} \mathrm{C}$. Chromosomal DNA was isolated and purified according to the method described by Yoon $e t$ al. (1996), with the modification that RNase T1 was used in combination with RNase A to minimize contamination with RNA. The $16 \mathrm{~S}$ rRNA gene was amplified by using a PCR with two universal primers as described previously (Yoon et al., 1998). Sequencing of the amplified 16S rRNA gene and phylogenetic analysis were performed as described by Yoon et al. (2003). Isoprenoid quinones were analysed as described by Komagata \& Suzuki (1987), using reversed-phase HPLC. For cellular fatty acid analysis, cell mass of strain SMK-142 ${ }^{\mathrm{T}}$ was harvested after cultivation for 7 days at $25{ }^{\circ} \mathrm{C}$ on MA. The fatty acids were extracted and fatty acid methyl esters were prepared according to the standard protocol of the MIDI/Hewlett Packard Microbial Identification System (Sasser, 1990). The DNA G+C content was determined using the method of Tamaoka \& Komagata (1984) with the modification that DNA was hydrolysed with nuclease P1 (Sigma); the resultant nucleotides were analysed with reversed-phase HPLC.

The morphological, cultural, physiological and biochemical characteristics of strain SMK-142 ${ }^{\mathrm{T}}$ are given in the species description (see below) and in Table 1. The sonicated cell extract of strain SMK-142 ${ }^{\mathrm{T}}$ showed no absorption maximum, but the acetone/methanol extract had absorption peak maxima at 451 and $477 \mathrm{~nm}$, indicating the presence of carotenoids. The almost-complete 16S rRNA gene sequence of strain SMK-142 ${ }^{\mathrm{T}}$ comprised $1482 \mathrm{nt}$. In the phylogenetic tree constructed using the neighbourjoining algorithm, strain SMK-142 ${ }^{\mathrm{T}}$ joined the lineage of Lutibacter litoralis with a bootstrap confidence value of $69.6 \%$ and this cluster joined the clade comprising the genera Tenacibaculum and Polaribacter with a bootstrap confidence value of $99.7 \%$ (Fig. 1). The same topology was also found in the trees constructed using the maximumlikelihood and maximum-parsimony algorithms (Fig. 1). Strain SMK- $142^{\mathrm{T}}$ exhibited $91.2 \%$ 16S rRNA gene

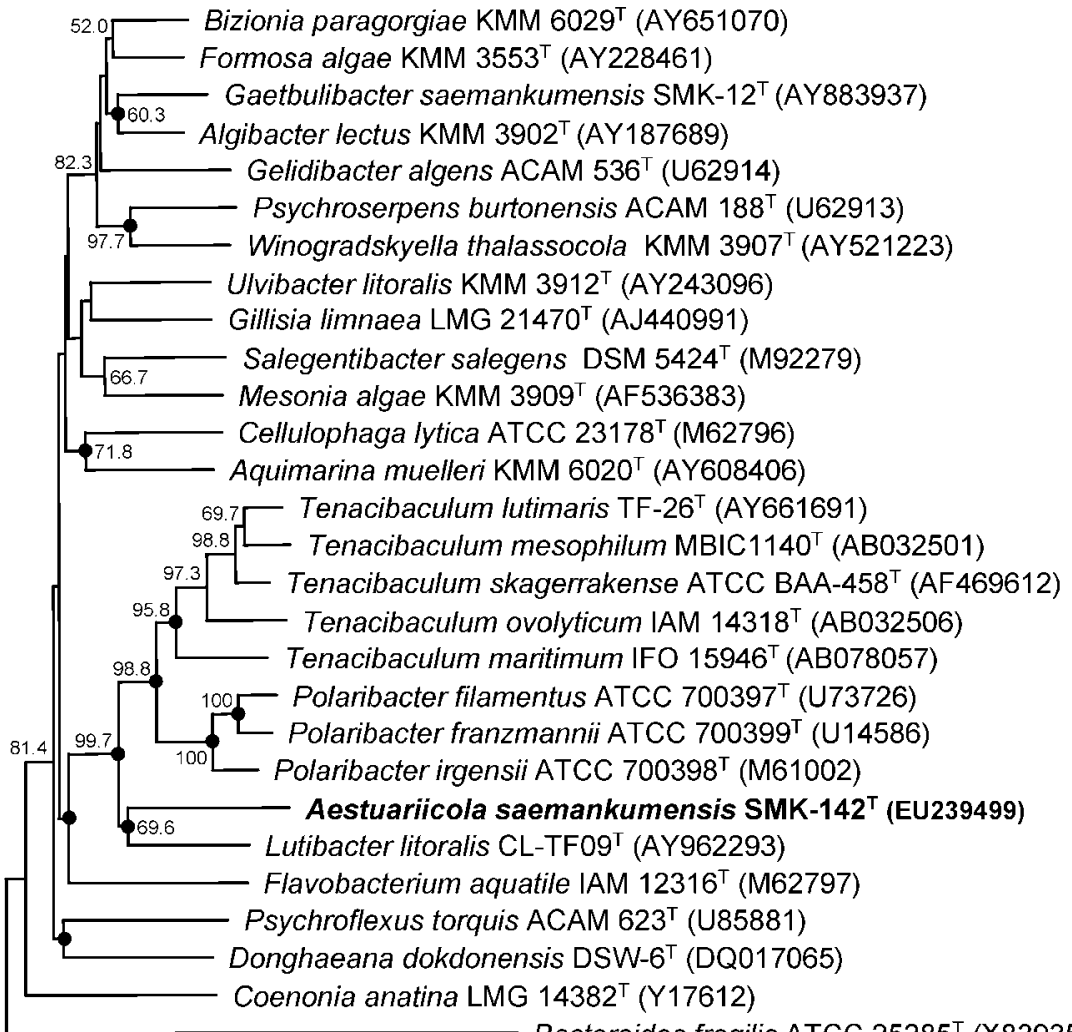

Bacteroides fragilis ATCC $25285^{\top}$ (X83935)

0.05

Fig. 1. Neighbour-joining phylogenetic tree, based on 16S rRNA gene sequences, showing the positions of strain SMK-142 ${ }^{\top}$ and other members of the family Flavobacteriaceae. Bootstrap percentages (based on 1000 replications) $>50 \%$ are shown at branching points. Filled circles indicate that the corresponding nodes were also recovered in the trees generated with the maximum-likelihood and maximum-parsimony algorithms. Bacteroides fragilis ATCC $25285^{\top}$ (GenBank accession no. X83935) was used as an outgroup. Bar, 0.05 substitutions per nucleotide position. 
sequence similarity with respect to the type strain of $L$. litoralis and showed less than $91.2 \%$ similarity with respect to the other species used in the phylogenetic analysis. The predominant isoprenoid quinone found in strain SMK$142^{\mathrm{T}}$ was MK-6, at a peak area ratio of approximately $96 \%$. The cellular fatty acid profile of strain SMK- $142^{\mathrm{T}}$ is shown in Table 2 together with that of $L$. litoralis CL-TF09 ${ }^{\mathrm{T}}$ analysed previously. The major fatty acids (constituting $>10 \%$ of total fatty acids) detected in strain SMK- $142^{\mathrm{T}}$ were iso- $\mathrm{C}_{15: 0}$, iso- $\mathrm{C}_{15: 1}$ and iso- $\mathrm{C}_{17: 0} 3-\mathrm{OH}$. The DNA $\mathrm{G}+\mathrm{C}$ content of strain SMK-142 ${ }^{\mathrm{T}}$ was $37.2 \mathrm{~mol} \%$.

The predominant menaquinone (MK-6) detected in strain SMK $-142^{\mathrm{T}}$ was the same as that found in phylogenetically related genera (Lutibacter, Tenacibaculum and Polaribacter) and in all other members of the family Flavobacteriaceae of the phylum Bacteroidetes (Suzuki et al., 2001; Nedashkovskaya et al., 2005; Bernardet \& Nakagawa, 2006; Bowman, 2006; Choi \& Cho, 2006; Yoon et al., 2006b; Jung et al., 2006). Phylogenetic analyses based on three different algorithms revealed that strain SMK-142 ${ }^{\mathrm{T}}$ clusters with $L$. litoralis (Fig. 1). However, the value for $16 \mathrm{~S}$ rRNA gene sequence similarity between strain SMK- $142^{\mathrm{T}}$ and L. litoralis CL-TF09 ${ }^{\mathrm{T}}$ was too low $(91.2 \%)$ to allow this novel strain to be assigned to the genus Lutibacter. The nature and proportion of the major fatty acids and the differences in several phenotypic properties served to differentiate strain SMK- $142^{\mathrm{T}}$ from members of the genera Lutibacter, Tenacibaculum and Polaribacter, although these differences may have resulted partly from different culture conditions (Tables 1 and 2). On the basis of its phylogenetic distinctiveness and differential chemotaxonomic and phenotypic properties, strain SMK-142 ${ }^{\mathrm{T}}$ represents a novel genus and species within the family Flavobacteriaceae, phylum Bacteroidetes, for which the name Aestuariicola saemankumensis gen. nov., sp. nov. is proposed.

\section{Description of Aestuariicola gen. nov.}

Aestuariicola [Aes.tu.a.ri.i.co'la. L. n. aestuarium part of the coast that overflows with seawater during a flood-tide and is left covered with mud or slime at ebb-tide, a tidal flat; $\mathrm{L}$. suff. - cola (from L. n. incola) a dweller, inhabitant; N.L. masc. n. Aestuariicola a dweller in a tidal flat].

Cells are Gram-negative, non-flagellated, non-gliding and pleomorphic. Catalase- and oxidase-positive. Strictly aerobic. The predominant menaquinone is MK-6. The major fatty acids are iso- $\mathrm{C}_{15: 0}$, iso- $\mathrm{C}_{15: 1}$ and iso- $\mathrm{C}_{17: 0} 3-\mathrm{OH}$. The type species is Aestuariicola saemankumensis.

\section{Description of Aestuariicola saemankumensis sp. nov.}

Aestuariicola saemankumensis (sae.man.kum.en'sis. N.L. masc. adj. saemankumensis of Saemankum, from where the organism was isolated).
Table 2. Cellular fatty acid contents (\%) of strain SMK $-142^{\top}$ and L. litoralis CL-TFO9 ${ }^{\top}$

Data for L. litoralis CL-TF09 ${ }^{\mathrm{T}}$ are from Choi \& Cho (2006). Fatty acids that represented $<1.0 \%$ in both strains were omitted. Both strains were grown on MA. Strain SMK- $142^{\mathrm{T}}$ was grown for 7 days at $25{ }^{\circ} \mathrm{C}$, whereas strain CL-TF09 ${ }^{\mathrm{T}}$ was grown for 1 day at $30{ }^{\circ} \mathrm{C}$. -, Not detected or $<1.0 \%$.

\begin{tabular}{|c|c|c|}
\hline Fatty acid & SMK-142 ${ }^{\mathrm{T}}$ & CL-TF09 $^{\mathrm{T}}$ \\
\hline \multicolumn{3}{|c|}{ Straight-chain fatty acids } \\
\hline $\mathrm{C}_{15: 0}$ & 4.0 & 1.7 \\
\hline $\mathrm{C}_{18: 0}$ & - & 1.3 \\
\hline \multicolumn{3}{|c|}{ Unsaturated fatty acids } \\
\hline $\mathrm{C}_{15: 1} \omega 6 c$ & 1.9 & 1.5 \\
\hline $\mathrm{C}_{17: 1} \omega 6 c$ & 2.6 & 1.0 \\
\hline \multicolumn{3}{|c|}{ Branched fatty acids } \\
\hline iso- $\mathrm{C}_{13: 0}$ & 6.5 & - \\
\hline anteiso- $\mathrm{C}_{13: 0}$ & 0.4 & 1.4 \\
\hline iso- $\mathrm{C}_{14: 0}$ & 0.7 & 2.2 \\
\hline iso- $\mathrm{C}_{15: 1} \mathrm{~F}^{*}$ & 1.2 & - \\
\hline iso- $\mathrm{C}_{15: 1} \mathrm{G}^{*}$ & 13.6 & 4.2 \\
\hline anteiso- $\mathrm{C}_{15: 1} \mathrm{~A}^{\star}$ & 0.7 & 1.6 \\
\hline iso- $\mathrm{C}_{15: 0}$ & 21.3 & 16.7 \\
\hline anteiso- $\mathrm{C}_{15: 0}$ & 1.9 & 15.1 \\
\hline iso- $\mathrm{C}_{16: 1} \mathrm{H}^{*}$ & 1.2 & 1.3 \\
\hline iso- $\mathrm{C}_{16: 0}$ & 1.4 & - \\
\hline iso- $\mathrm{C}_{17: 1} \omega 9 c$ & 3.7 & - \\
\hline \multicolumn{3}{|c|}{ Hydroxy fatty acids } \\
\hline iso- $\mathrm{C}_{15: 0} 3-\mathrm{OH}$ & 7.4 & 17.4 \\
\hline $\mathrm{C}_{15: 0} 2-\mathrm{OH}$ & 1.2 & 2.1 \\
\hline $\mathrm{C}_{15: 0} 3-\mathrm{OH}$ & - & 1.5 \\
\hline iso- $\mathrm{C}_{16: 0} 3-\mathrm{OH}$ & 3.3 & 13.4 \\
\hline iso- $\mathrm{C}_{17: 0} 3-\mathrm{OH}$ & 12.5 & 3.9 \\
\hline $\mathrm{C}_{17: 0} 2-\mathrm{OH}$ & 0.7 & 3.6 \\
\hline \multicolumn{3}{|l|}{ Summed features $\dagger$} \\
\hline 1 & - & 1.1 \\
\hline 3 & 7.6 & 1.0 \\
\hline 4 & 1.3 & - \\
\hline \multicolumn{3}{|c|}{ Unknown fatty acids $\ddagger$} \\
\hline ECL 11.543 & 0.6 & 2.3 \\
\hline ECL 13.565 & 1.9 & - \\
\hline
\end{tabular}

*The double-bond position, indicated by a capital letter, is unknown. $\dagger$ Summed features represent groups of two or three fatty acids which could not be separated by GLC with the MIDI system. Summed feature 1 contained iso- $\mathrm{C}_{15: 1}$ and/or $\mathrm{C}_{13: 0} 3-\mathrm{OH}$; summed feature 3 contained $\mathrm{C}_{16: 1} \omega 7 c$ and/or iso- $\mathrm{C}_{15: 0} \quad 2-\mathrm{OH}$; summed feature 4 contained iso- $\mathrm{C}_{17: 1}$ and/or anteiso- $\mathrm{C}_{17: 1}$.

$\ddagger$ ECL, Equivalent chain length.

Displays the following properties in addition to those given in the genus description. Cells are rod-shaped, oval or coccoid and $0.3-0.5 \mu \mathrm{m}$ in diameter and $0.5-7.0 \mu \mathrm{m}$ in length; cells greater than $10.0 \mu \mathrm{m}$ in length occur in older cultures. Colonies on MA are circular with entire edges, convex, smooth, glistening, yellow and $1.0-2.0 \mathrm{~mm}$ in diameter after 7 days incubation at $25{ }^{\circ} \mathrm{C}$. Optimal growth 
occurs at $25{ }^{\circ} \mathrm{C}$. Growth occurs at 4 and $33{ }^{\circ} \mathrm{C}$, but not at $34{ }^{\circ} \mathrm{C}$. The optimal $\mathrm{pH}$ for growth is 7.0-8.0; growth occurs at $\mathrm{pH} 5.5$, but not at $\mathrm{pH}$ 5.0. Optimal growth occurs in the presence of $2 \%(\mathrm{w} / \mathrm{v}) \mathrm{NaCl}$; growth occurs in the presence of $0.5-4 \%(\mathrm{w} / \mathrm{v}) \mathrm{NaCl}$. Carotenoid pigments are produced, but flexirubin-type pigments are not produced. Tweens 20, 40 and 60 are weakly hydrolysed, but casein, hypoxanthine, xanthine, L-tyrosine and Tween 80 are not hydrolysed. $\mathrm{H}_{2} \mathrm{~S}$ is not produced. Growth occurs on Casamino acids, peptone and tryptone, but not on Larabinose, cellobiose, D-fructose, D-galactose, D-glucose, maltose, D-mannose, trehalose, D-xylose, acetate, benzoate, L-malate, salicin, formate, L-arginine, L-ornithine, DLaspartate or DL-cysteine. Susceptible to carbenicillin, cephalothin, chloramphenicol, lincomycin, novobiocin, oleandomycin and tetracycline, but not to ampicillin, gentamicin, kanamycin, neomycin, penicillin G, polymyxin $B$ or streptomycin. In the API ZYM system, alkaline phosphatase, leucine arylamidase, valine arylamidase, cystine arylamidase, acid phosphatase and $N$-acetyl- $\beta$-glucosaminidase activities are present, esterase $(\mathrm{C} 4)$ and esterase lipase (C8) activities are weak and lipase (C14), trypsin, $\alpha$-chymotrypsin, naphthol-AS-BI phosphohydrolase, $\alpha$-galactosidase, $\beta$ galactosidase, $\beta$-glucuronidase, $\alpha$-glucosidase, $\beta$-glucosidase, $\alpha$-mannosidase and $\alpha$-fucosidase activities are absent. The major fatty acids ( $>10 \%$ of total fatty acids) are iso- $\mathrm{C}_{15: 0}$, iso- $\mathrm{C}_{15: 1}$ and iso- $\mathrm{C}_{17: 0} 3-\mathrm{OH}$. The DNA G $+\mathrm{C}$ content is $37.2 \mathrm{~mol} \%$ (determined by HPLC). Other phenotypic characteristics are given in Table 1.

The type strain, SMK $-142^{\mathrm{T}}\left(=\right.$ KCTC $22171^{\mathrm{T}}=$ CCUG $55329^{\mathrm{T}}$ ), was isolated from a tidal flat sediment at Saemankum on the Yellow Sea coast of Korea.

\section{Acknowledgements}

This work was supported by the 21C Frontier Program of Microbial Genomics and Applications (grant MG05-0401-2-0) and the Support and Application Project of Biological Resources (grant M10508050004-06N0805-00410) from the Ministry of Science and Technology (MOST) of the Republic of Korea.

\section{References}

Bernardet, J.-F. \& Nakagawa, Y. (2006). An introduction to the family Flavobacteriaceae. In The Prokaryotes: a Handbook on the Biology of Bacteria, 3rd edn, vol. 7, pp. 455-480. Edited by M. Dworkin, S. Falkow, E. Rosenberg, K.-H. Schleifer \& E. Stackebrandt. New York: Springer.

Bowman, J. P. (2000). Description of Cellulophaga algicola sp. nov., isolated from the surfaces of Antarctic algae, and reclassification of Cytophaga uliginosa (ZoBell and Upham 1944) Reichenbach 1989 as Cellulophaga uliginosa comb. nov. Int J Syst Evol Microbiol 50, 18611868.

Bowman, J. P. (2006). The marine clade of the family Flavobacteriaceae: the genera Aequorivita, Arenibacter, Cellulophaga, Croceibacter, Formosa, Gelidibacter, Gillisia, Maribacter, Mesonia, Muricauda, Polaribacter, Psychroflexus, Psychroserpens, Robiginitalea, Salegentibacter, Tenacibaculum, Ulvibacter, Vitellibacter, and Zobellia. In The Prokaryotes: a Handbook on the Biology of Bacteria, 3rd edn, vol. 7, pp. 677-694. Edited by M. Dworkin, S. Falkow, E. Rosenberg, K.-H. Schleifer \& E. Stackebrandt. New York: Springer.

Bruns, A., Rohde, M. \& Berthe-Corti, L. (2001). Muricauda ruestringensis gen. nov., sp. nov., a facultatively anaerobic, appendaged bacterium from German North Sea intertidal sediment. Int $J$ Syst Evol Microbiol 51, 1997-2006.

Choi, D. H. \& Cho, B. C. (2006). Lutibacter litoralis gen. nov., sp. nov., a marine bacterium of the family Flavobacteriaceae isolated from tidal flat sediment. Int J Syst Evol Microbiol 56, 771-776.

Choi, D. H., Kim, Y.-G., Hwang, C. Y., Yi, H., Chun, J. \& Cho, B. C. (2006). Tenacibaculum litoreum sp. nov., isolated from tidal flat sediment. Int J Syst Evol Microbiol 56, 635-640.

Cowan, S. T. \& Steel, K. J. (1965). Manual for the Identification of Medical Bacteria. London: Cambridge University Press.

Gosink, J. J., Woese, C. R. \& Staley, J. T. (1998). Polaribacter gen. nov., with three new species, $P$. irgensii sp. nov., $P$. franzmannii sp. nov. and $P$. filamentus sp. nov., gas vacuolate polar marine bacteria of the Cytophaga-Flavobacterium-Bacteroides group and reclassification of 'Flectobacillus glomeratus' as Polaribacter glomeratus comb. nov. Int J Syst Bacteriol 48, 223-235.

Jung, S.-Y., Kang, S.-J., Lee, M.-H., Lee, S.-Y., Oh, T.-K. \& Yoon, J.-H. (2005). Gaetbulibacter saemankumensis gen. nov., sp. nov., a novel member of the family Flavobacteriaceae isolated from a tidal flat sediment in Korea. Int J Syst Evol Microbiol 55, 1845-1849.

Jung, S.-Y., Oh, T.-K. \& Yoon, J.-H. (2006). Tenacibaculum aestuarii sp. nov., isolated from a tidal flat sediment in Korea. Int J Syst Evol Microbiol 56, 1577-1581.

Kim, I.-G., Lee, M.-H., Jung, S.-Y., Song, J. J., Oh, T.-K. \& Yoon, J.-H. (2005). Exiguobacterium aestuarii sp. nov. and Exiguobacterium marinum sp. nov., isolated from a tidal flat of the Yellow Sea in Korea. Int J Syst Evol Microbiol 55, 885-889.

Komagata, K. \& Suzuki, K. (1987). Lipid and cell-wall analysis in bacterial systematics. Methods Microbiol 19, 161-207.

Lányí, B. (1987). Classical and rapid identification methods for medically important bacteria. Methods Microbiol 19, 1-67.

Lim, J.-M., Jeon, C. O., Lee, J.-C., Song, S.-M., Kim, K.-Y. \& Kim, C.-J. (2006). Marinimicrobium koreense gen. nov., sp. nov. and Marinimicrobium agarilyticum sp. nov., novel moderately halotolerant bacteria isolated from tidal flat sediment in Korea. Int J Syst Evol Microbiol 56, 653-657.

Nam, Y.-D., Chang, H.-W., Park, J. R., Kwon, H.-Y., Quan, Z.-X., Park, Y.-H., Lee, J.-S., Yoon, J.-H. \& Bae, J.-W. (2007). Pseudoalteromonas marina sp. nov., a marine bacterium isolated from tidal flats of the Yellow Sea, and reclassification of Pseudoalteromonas sagamiensis as Algicola sagamiensis comb. nov. Int J Syst Evol Microbiol 57, 12-18.

Nedashkovskaya, O. I., Kim, S. B., Lysenko, A. M., Kalinovskaya, N. I., Mikhailov, V. V., Kim, I. S. \& Bae, K. S. (2005). Polaribacter butkevichii sp. nov., a novel marine mesophilic bacterium of the family Flavobacteriaceae. Curr Microbiol 51, 408-412.

Reichenbach, H. (1992). The order Cytophagales. In The Prokaryotes. 2nd edn, vol.4, pp. 3631-3675. Edited by A. Balows, H. G. Trüper, M. Dworkin, W. Harder \& K. H. Schleifer. New York: Springer.

Sasser, M. (1990). Identification of bacteria by gas chromatography of cellular fatty acids, MIDI Technical Note 101. Newark, DE: MIDI Inc.

Sheu, S.-Y., Lin, K.-Y., Chou, J.-H., Chang, P.-S., Arun, A. B., Young, C.-C. \& Chen, W.-M. (2007). Tenacibaculum litopenaei sp. nov., isolated from a shrimp mariculture pond. Int J Syst Evol Microbiol 57, 1148-1153.

Suzuki, M., Nakagawa, Y., Harayama, S. \& Yamamoto, S. (2001). Phylogenetic analysis and taxonomic study of marine Cytophaga-like 
bacteria: proposal for Tenacibaculum gen. nov. with Tenacibaculum maritimum comb. nov. and Tenacibaculum ovolyticum comb. nov., and description of Tenacibaculum mesophilum sp. nov. and Tenacibaculum amylolyticum sp. nov. Int J Syst Evol Microbiol 51, 1639-1652.

Tamaoka, J. \& Komagata, K. (1984). Determination of DNA base composition by reversed-phase high-performance liquid chromatography. FEMS Microbiol Lett 25, 125-128.

Yi, H. \& Chun, J. (2004). Hongiella mannitolivorans gen. nov., sp. nov., Hongiella halophila sp. nov. and Hongiella ornithinivorans sp. nov., isolated from tidal flat sediment. Int J Syst Evol Microbiol 54, 157-162.

Yoon, J.-H., Kim, H., Kim, S.-B., Kim, H.-J., Kim, W. Y., Lee, S. T., Goodfellow, M. \& Park, Y.-H. (1996). Identification of Saccharomonospora strains by the use of genomic DNA fragments and rRNA gene probes. Int J Syst Bacteriol 46, 502-505.
Yoon, J.-H., Lee, S. T. \& Park, Y.-H. (1998). Inter- and intraspecific phylogenetic analysis of the genus Nocardioides and related taxa based on 16S rDNA sequences. Int J Syst Bacteriol 48, 187-194.

Yoon, J.-H., Kim, I.-G., Kang, K. H., Oh, T.-K. \& Park, Y.-H. (2003). Bacillus marisflavi sp. nov. and Bacillus aquimaris sp. nov., isolated from sea water of a tidal flat of the Yellow Sea in Korea. Int J Syst Evol Microbiol 53, 1297-1303.

Yoon, J.-H., Oh, T.-K. \& Park, Y.-H. (2004). Kangiella koreensis gen. nov., sp. nov. and Kangiella aquimarina sp. nov., isolated from a tidal flat of the Yellow Sea in Korea. Int J Syst Evol Microbiol 54, 1829-1835.

Yoon, J.-H., Kang, S.-J., Jung, S.-Y., Oh, H. W. \& Oh, T.-K. (2006a). Gaetbulimicrobium brevivitae gen. nov., sp. nov., a novel member of the family Flavobacteriaceae isolated from a tidal flat of the Yellow Sea in Korea. Int J Syst Evol Microbiol 56, 115-119.

Yoon, J.-H., Kang, S.-J. \& Oh, T.-K. (2006b). Polaribacter dokdonensis sp. nov., isolated from seawater. Int J Syst Evol Microbiol 56, 1251-1255. 